\title{
PENGEMBANGAN SOAL HOTS DENGAN WONDERSHARE QUIZ CREATOR SEBAGAI MEDIA DISPLAY PADA MATERI STOIKIOMETRI KELAS X
}

\author{
Siti Imroatus Sa'adah ${ }^{\mathbf{1}^{*}}$, Rasmiwetti ${ }^{1}$ dan Roza Linda ${ }^{\mathbf{1}}$ \\ ${ }^{1}$ Program Studi Pendidikan Kimia, FKIP, Universitas Riau, Jl. H. R. Soebrantas KM \\ 12,5 Panam, Pekanbaru, 28293, Indonesia \\ *E-mail: 123imro@gmail.com
}

\begin{abstract}
ABSTRAK
Penelitian ini bertujuan untuk menghasilkan evaluasi berupa Soal HOTS (High Order Thinking Skill) dengan wondershare quiz creator sebagai media display pada materi stoikiometri yang valid dan reliabel. Penelitian dirancang menggunakan desain penelitian dan pengembangan $(R \& D)$ dengan model pengembangan Plomp. Pengguna terdiri dari tiga orang guru dan 45 peserta didik kelas XI di sekolah SMA Cendana Pekanbaru, SMA 8 Pekanbaru dan MAN 2 Model Pekanbaru. Objek penelitian adalah soal HOTS dengan wondershare quiz creator sebagai media display. Teknik pengumpulan data dilakukan dengan studi pustaka dan studi lapangan. Data penelitian diperoleh dengan memvalidasi soal HOTS dengan wondershare quiz creator sebagai media display kepada lima orang validator (tiga validator materi dan dua validator media) dan uji coba soal HOTS oleh pengguna. Teknik analisis data yang digunakan adalah analisis deskriptif. Hasil penelitian memperlihatkan skor rata-rata validator materi berdasarkan aspek materi dengan persentase 95,34\%, aspek konstruksi 95,20\% dan aspek bahasa 93,14\%. Menurut validator media berdasarkan aspek substansi materi dengan persentase $84,00 \%$, desain pembelajaran $86,00 \%$, tampilan (komunikasi visual) $84,00 \%$ dan pemanfaatan software $88,57 \%$. Skor respon pengguna oleh guru dan peserta didik masing-masing $90,67 \%$ dan $91,20 \%$ dengan kriteria sangat baik.
\end{abstract}

Kata kunci: HOTS, stoikiometri, wondershare quiz creator

\begin{abstract}
This research aimed to produce an evaluation in the form of HOTS (High order Thinking Skill) questions with wondershare quiz creator as display media on stoichiometric materials that were valid and reliable. The research was designed by research and development $(R \& D)$ design with Plomp design research. Users consisting of three teachers and 45 students of class XI at SMA Cendana Pekanbaru, SMAN 8 Pekanbaru, and MAN 2 Model Pekanbaru. The object of the research is the matter of HOTS with wondershare quiz creator as a media display. Data collection techniques were carried out with literature studies and field studies. The research data was obtained by validating HOTS questions with wondershare quiz creator as a media display to five validators (three material validators and two media validators) and user testing of HOTS. The data analysis technique used was descriptive analysis. The results showed an average score of the material validator based on material aspects with a percentage of $95.34 \%$, construction aspects $95.20 \%$ and language aspects $93.14 \%$. According to the media validator based on the substance content aspect with a percentage of $84.00 \%$, learning design $86.00 \%$, display $84.00 \%$ and software utilization $88.57 \%$. User response scores by teachers and learners respectively were $90.67 \%$ and $91.20 \%$ with very good criteria.
\end{abstract}

Keywords: HOTS, stoichiometry, wondershare quiz creator

DOI: http://doi.org/10.15575/jtk.v4i2.5469 
Pengembangan Soal HOTS dengan Wondershare Quiz Creator sebagai Media Display pada Materi Stoikiometri Kelas X

\section{PENDAHULUAN}

Belajar adalah proses interaksi antara individu dan lingkungannya yang dapat terjadi kapan saja dan dimana saja. Guru bukan lagi sebagai pemberi informasi, namun sebagai fasilitator dalam proses pembelajaran (Sanjaya, 2008). Peran guru sebagai fasilitator adalah menyediakan bahan ajar, media pembelajaran dan memberikan evaluasi terhadap peserta didik.

Bahan ajar merupakan salah satu bagian penting dalam proses pembelajaran. Sebuah bahan ajar paling tidak mencakup petunjuk belajar (petunjuk peserta didik/guru), kompetensi yang akan dicapai, informasi pendukung, latihan, petunjuk kerja dapat berupa lembar kerja dan evaluasi (Depdiknas, 2008). Salah satu bahan ajar yang digunakan dalam pembelajaran adalah soal evaluasi.

Arifin (2014) menyatakan bahwa alat evaluasi yang baik adalah alat evaluasi yang memenuhi syarat-syarat atau kaidah-kaidah tertentu, dapat memberikan data yang akurat sesuai dengan fungsinya, dan hanya mengukur sampel perilaku tertentu. Karateristik alat evaluasi yang baik yaitu: valid, reliable, relevan, representatif, praktis, dan spesifik. Pada proses pembelajaran terdapat berbagai macam alat evaluasi yang digunakan untuk menilai proses dan hasil pendidikan yang telah dilakukan terhadap peserta didik, salah satunya bentuk soal. Soal terbagi menjadi dua jenis yaitu soal uraian dan soal bentuk objektif.

Berbagai ilmu dipelajari dalam pembelajaran yang dilakukan di institusi pendidikan Sekolah Menengah Atas (SMA). Salah satu pembelajaran tersebut adalah IPA. Kimia sebagai bagian dari IPA diperoleh dan dikembangkan berdasarkan percobaan untuk mencari jawaban atas pertanyaan apa, mengapa, dan bagaimana tentang gejalagejala alam, khususnya yang berkaitan dengan komposisi, struktur, sifat, dinamika dan energetika zat (Kemendikbud, 2017).

Hasil wawancara dan data sebaran kuisioner peneliti di SMA Negeri 8 Pekanbaru, SMA Cendana Pekanbaru, dan MAN 2 Model Pekanbaru yang dilakukan pada bulan November 2018, menunjukkan bahwa soal evaluasi yang digunakan sedang mengupayakan soal berorientasi HOTS. Saat ini soal yang digunakan masih pada level mengingat $\left(C_{1}\right)$, memahami $\left(C_{2}\right)$, dan menerapkan $\left(\mathrm{C}_{3}\right)$. Hal ini disebabkan penyusunan soal berbasis HOTS bukanlah suatu hal yang mudah. Oleh karena itu, perlu dilakukan pengembangan soal HOTS yang dapat digunakan melatih kemampuan berpikir tingkat tinggi peserta didik. Data sebaran kuisioner prariset yang telah dilakukan menunjukkan bahwa sebanyak 72,28\% responden memahami pembelajaran kimia pada pokok bahasan stoikiometri, 50,42\% responden aktif dalam pembelajaran kimia pada pokok bahasan stoikiometri, 30,79\% responden kritis dan kreatif pada pembelajaran kimia pokok bahasan stoikiometri dan 20,47\% responden yang mengenal soal HOTS. Hal ini menunjukkan bahwa peserta didik telah memahami pokok bahasan stoikiometri namun belum mengenal secara baik soal dengan keterampilan berpikir tingkat tinggi dan peserta didik masih belum terbiasa mengerjakan soal HOTS secara mandiri.

Materi stoikiometri merupakan salah satu materi pembelajaran kimia di Sekolah Menengah Atas (SMA) yang menuntut adanya pemahaman konsep dan terampil dalam perhitungan. Konsep-konsep dasar sederhana terkait stoikiometri dijabarkan dalam bentuk ungkapan/persamaan matematis hingga 
Pengembangan Soal HOTS dengan Wondershare Quiz Creator sebagai Media Display pada Materi Stoikiometri Kelas X

membangun konsep yang bersifat kompleks. Pokok bahasan stoikiometri ini perlu bertahan lama diingatan peserta didik karena ruang lingkup materi stoikiometri merupakan dasardasar materi selanjutnya sehingga perlu dipahami secara mendalam dengan cara melatih kemampuan peserta didik dalam mengerjakan soal HOTS.

Kemampuan berpikir tingkat tinggi ditinjau dari dua segi yaitu menurut Taksonomi Bloom dan Brookhart (2010). Dimensi proses berpikir dalam Taksonomi Bloom terdiri atas kemampuan mengetahui (knowing- $C_{1}$ ), memahami (understanding- $\mathrm{C}_{2}$ ), menerapkan (applying- $\left.\mathrm{C}_{3}\right)$, menganalisis (analyzing- $\mathrm{C}_{4}$ ), mengevaluasi (evaluating- $\mathrm{C}_{5}$ ), dan mengkreasi (creating- $\mathrm{C}_{6}$ ). Pencapaian pada kemampuan berpikir tingkat tinggi menurut Taksonomi Bloom pada ranah $\mathrm{C}_{4}, \mathrm{C}_{5}$, dan $\mathrm{C}_{6}$. Kemampuan berpikir tingkat tinggi seseorang diketahui dengan menggunakan indikator-indikator yang mampu mengukur kemampuan tersebut (Anderson dan Krathwohl, 2002). Brookhart (2010) menyatakan indikator-indikator soal HOTS secara umum terdiri dari keterampilan berpikir kritis, problem solving atau proses dalam menemukan masalah dan keterampilan berpikir kreatif.

Permendikbud No. 59 Tahun 2014 tentang Kurikulum 2013 Sekolah Menengah Atas/Madrasah Aliyah menyatakan bahwa salah satu dasar penyempurnaan kurikulum adalah adanya tantangan internal dan eksternal. Tantangan eksternal meliputi arus globalisasi yang ditandai dengan perkembangan ekonomi dan teknologi semakin pesat. Perkembangan ekonomi dan teknologi mengubah bentuk masa depan yang harus dihadapi peserta didik. Tantangan masa depan menuntut pembelajaran, khususnya pada pembelajaran yang mengembangkan keterampilan berpikir tingkat tinggi atau dikenal dengan higher order thinking skill (HOTS). Pembelajaran sains diharapkan dapat menghantarkan peserta didik untuk memenuhi kemampuan abad 21 yang lebih dititik beratkan pada kemampuan berpikir dan komunikasi, maka pembelajaran dipandang bukan hanya untuk pengalihan pengetahuan dan keterampilan, tetapi juga untuk membangun kemampuan berpikir tingkat tinggi (Kemendikbud, 2017)

Perkembangan ilmu pengetahuan dan teknologi, khususnya teknologi informasi atau Information and Communication Technologies (ICT) sangat berpengaruh dalam proses pembelajaran. Salah satu faktor yang mempengaruhi penggunaan alat evaluasi berbasis ICT ini karena alat evaluasi konvensional dalam pelaksanaanya belum efektif, diantaranya membutuhkan biaya yang cukup banyak, lamanya waktu pemeriksaan jawaban, dan kesalahan dalam pengkoreksian karena dilakukan secara manual. Salah satu aplikasi yang dapat digunakan untuk membuat alat evaluasi berbasis ICT adalah wondershare quiz creator yang merupakan perangkat lunak untuk pembuatan soal, kuis atau tes secara online dan offline yang tidak memerlukan kemampuan penguasaan bahasa pemprograman untuk mengoperasikannya sehingga sangat mudah digunakan atau user friendly (Hernawati, 2009).

Soal dengan wondershare quiz creator sebagai media display menyajikan suatu evaluasi untuk meningkatkan kemampuan peserta didik dalam berfikir kritis. Penelitian lqbal dkk. (2018) dengan judul "Pengembangan Alat Evaluasi Berbasis Wondershare Quiz Creator pada Materi Koloid Kelas XI di SMA Koperasi Pontianak" menunjukkan bahwa aplikasi wondershare quiz creator pada materi koloid layak digunakan guru dan peserta didik dengan validasi ahli media sebesar 90,69\% 
Pengembangan Soal HOTS dengan Wondershare Quiz Creator sebagai Media Display pada Materi Stoikiometri Kelas X

(sangat valid), ahli materi 83,98\% (sangat valid) dan uji coba yang dilakukan kelompok kecil untuk melihat respon pengguna terhadap wondershare quiz creator mendapatkan persentase sebesar 79,07\% (kategori baik). Kemudian dalam penelitian Afriani dkk. (2018) dengan judul "Pengembangan Instrumen Asesmen Pengetahuan Berbasis HOTS pada Materi Elektrolit dan Nonelektrolit" menunjukkan bahwa instrumen asesmen pengetahuan berbasis HOTS pada materi elektrolit dan nonelektrolit layak digunakan guru dan peserta didik dengan validasi ahli materi pada aspek keterbacaan 92,30\% (sangat valid), aspek konstruksi 88,33\% (valid), dan aspek kesesuaian isi materi $82 \%$ (valid) serta uji coba yang dilakukan kelompok kecil untuk melihat tes. Hasil respon guru diperoleh persentase $89,23 \%$ (kategori sangat baik) dan respon peserta didik terhadap soal HOTS mendapatkan persentase $87,08 \%$ (kategori sangat baik).

Berdasarkan latar belakang yang telah diuraikan, maka penelitian ini bertujuan untuk untuk mengembangkan soal HOTS dengan wondershare quiz creator sebagai media display pada pokok bahasan stoikiometri untuk kelas $X$ tingkat SMA/MA sederajat yang valid dan reliabel.

\section{METODE PENELITIAN}

Penelitian ini dilaksanakan di Program Studi Pendidikan Kimia FKIP Universitas Riau Pekanbaru dengan uji coba di SMA Cendana Pekanbaru, SMA Negeri 8 Pekanbaru, dan MAN 2 Model Pekanbaru. Pengembangan soal HOTS dengan wondershare quiz creator sebagai media display pada pokok bahasan stoikiometri untuk kelas $X$ tingkat SMA/MA sederajat dirancang menggunakan desain penelitian dan pengembangan berdasarkan Research \& Development $(R \& D)$.
Soal HOTS dengan wondershare quiz creator sebagai media display pada pokok bahasan stoikiometri untuk kelas $X$ tingkat SMA/MA sederajat dikembangkan menggunakan model pengembangan Plomp yang terdiri atas fase investigasi awal (prelimenary investigation), fase desain (design), fase realisasi/konstruksi (realization/construction) dan fase validasi, uji coba dan revisi (evaluation, test and revision), dan fase implementasi (implementation) (Rochmad, 2012). Soal HOTS dengan wondershare quiz creator sebagai media display yang dikembangkan peneliti dinilai oleh lima orang validator untuk menguji kevalidannya, terdiri atas tiga orang validator materi dan dua orang validator media. Proses validasi dilakukan lebih dari tiga kali dengan penilaian oleh validator dilakukan diakhir proses validasi. Hal ini bertujuan untuk memperoleh hasil yang valid berdasarkan aspek validator materi dan media. Hasil validasi kemudian dianalisis guna menentukan kegiatan selanjutnya.

Teknik analisis data yang digunakan dalam validasi soal HOTS dengan aspek penilaian dilakukan terhadap aspek materi, konstruksi, dan bahasa dalam bentuk skala penilaian. Jenis skala yang digunakan adalah skala Likert dengan skor 1 sampai 5 . Kevalidan soal HOTS melakukan perhitungan persentase nilai validasi menggunakan rumus menurut Arikunto 2010).

$$
\bar{X}=\frac{\sum x}{n}
$$

Keterangan:

\begin{tabular}{|c|c|}
\hline & \\
\hline$X$ & $=$ nilai rata-rata \\
\hline$\sum x$ & $=$ ju \\
\hline & $=$ jumlah \\
\hline
\end{tabular}


Pengembangan Soal HOTS dengan Wondershare Quiz Creator sebagai Media Display pada Materi Stoikiometri Kelas X

Tabel 1. Skala Likert untuk Validasi Materi, Konstruksi, dan Bahasa

\begin{tabular}{|c|c|}
\hline Persentase & Keterangan \\
\hline $0-20$ & Sangat lemah/tidak valid (diganti) \\
\hline $21-40$ & Lemah/ kurang valid \\
\hline $41-60$ & Cukup/cukup valid \\
\hline $61-80$ & Kuat/valid \\
\hline $81-100$ & Sangat kuat/sangat valid \\
\hline
\end{tabular}

(Riduwan. 2013)

Penginterpretasi nilai validitas yang diperoleh dari perhitungan di atas, maka digunakan pengklasifikasian validitas seperti yang ditunjukkan pada Tabel 1.

Analisis validitas soal HOTS dengan wondershare quiz creator sebagai media display pada pokok bahasan stoikiometri untuk kelas $X$ tingkat SMA/MA sederajat dilakukan terhadap aspek subtansi materi, desain pembelajaran, tampilan (komunikasi visual) dan pemanfaatan software. Jenis skala yang digunakan adalah skala Likert dengan skor 1 sampai 5 . Untuk mengetahui kevalidan soal HOTS ini dilakukan perhitungan persentase nilai validasi dengan menggunakan rumus menurut Rohmad dkk. (2013).

$$
\text { Persentase }=\frac{\text { skor yang diperoleh }}{\text { skor maksimum }} \times 100 \%
$$

Penginterpretasi nilai validitas yang diperoleh dari perhitungan di atas, maka digunakan pengklasifikasian validitas seperti yang ditunjukkan pada Tabel 2.

Tabel 2. Kriteria Kelayakan Analisa Persentase

\begin{tabular}{|l|l|}
\hline Persentase & Keterangan \\
\hline $85,33-100$ & Sangat Baik/Valid/Layak \\
\hline $69,33-84$ & Baik/Valid/Layak \\
\hline $53,33-68$ & $\begin{array}{l}\text { Cukup Baik/Cukup Valid/Cukup } \\
\text { Layak }\end{array}$ \\
\hline $37,33-52$ & Tidak Baik \\
\hline $20-36$ & Sangat Tidak Baik \\
\hline
\end{tabular}

(Widoyoko, 2012)
Data penilaian dan saran terkait respon pengguna diperoleh melalui uji coba kepada total tiga guru kimia dan 45 peserta didik SMA yang sebelumnya telah mempelajari materi stoikiometri. Uji coba dilakukan di tiga SMA berbeda sebagai representatif dari institusi pendidikan SMA swasta yakni SMA Cendana Pekanbaru, institusi Pendidikan SMA negeri pada tingkatan wilayah ibukota provinsi yakni SMAN 8 Pekanbaru, dan institusi pendidikan SMA di bawah naungan Kementerian Agama pada tingkatan wilayah ibu kota provinsi yakni MAN 2 Model Pekanbaru.

Angket respon guru dan peserta didik disusun berdasarkan skala Likert dengan interval sangat setuju sampai tidak setuju dengan lima pilihan pernyataan positif. Penilaian dari semua respon guru dan peserta didik dirataratakan dan hasil penilaian yang diperoleh diintrepretasikan ke dalam Tabel 3.

Tabel 3. Kriteria Respon Guru dan Peserta Didik

\begin{tabular}{|c|c|}
\hline Persentase (\%) & $\begin{array}{c}\text { Kriteria Respon Peserta } \\
\text { Didik }\end{array}$ \\
\hline $80,00-100$ & Sangat Baik \\
\hline $60,00-79,99$ & Baik \\
$40,00-59,00$ & Cukup Baik \\
\hline $20,00-39,99$ & Kurang Baik \\
\hline $0,00-19,99$ & Tidak Baik \\
\hline
\end{tabular}

(Yamasari, 2010)

Uji reliabillitas dilakukan dengan menggunakan rumus Spearman Brown. Adapun rumus Spearman Brown menurut Sugiyono (2005) sebagai berikut:

Keterangan:

$$
r_{i}=\frac{2 r_{b}}{1+r_{b}}
$$

$\mathrm{r}_{\mathrm{i}}=$ reliabilitas internal seluruh instrumen

$r_{b}=$ korelasi product moment antara belahan pertama dan kedua 
Tabel 4. Kriteria Reliabilitas

\begin{tabular}{|l|l|}
\hline Reliabilitas & Kriteria \\
\hline $0,81-1,00$ & Sangat tinggi \\
\hline $0,61-0,80$ & Tinggi \\
\hline $0,41-0,60$ & Cukup \\
\hline $0,21-0,40$ & Rendah \\
\hline $0,01-0,20$ & Sangat rendah \\
\hline
\end{tabular}

(Arikunto, 2010)

Analisis taraf kesukaran digunakan untuk mengetahui tingkat kesukaran butir soal. Rumus yang digunakan untuk mengetahui tingkat kesukaran soal menurut Arikunto (2010) sebagai berikut:

$$
P=\frac{B}{J S}
$$

Keterangan :

$$
\begin{aligned}
\mathrm{P} \quad= & \text { indeks kesukaran } \\
\mathrm{B} \quad= & \text { banyaknya peserta didik yang } \\
& \text { menjawab soal itu dengan benar } \\
\text { JS } & \text { jumlah seluruh peserta didik yang } \\
& \text { mengikuti tes }
\end{aligned}
$$

Tabel 5. Kriteria Taraf Kesukaran

\begin{tabular}{|c|c|}
\hline Taraf Kesukaran & Kriteria \\
\hline $0,00-0,30$ & Sukar \\
\hline $0,31-0,70$ & Sedang \\
\hline $0,71-1,00$ & Mudah \\
\hline
\end{tabular}

(Arikunto, 2010)

Daya pembeda soal pilihan jamak dianalisis menggunakan rumus menurut Sumarna (2005) sebagai berikut:

$$
\mathrm{DP}=\frac{\sum A}{n_{A}}-\frac{\sum B}{n_{B}}
$$

Keterangan :

$\mathrm{DP} \quad=$ Indeks yang beda

$\Sigma \mathrm{A}=$ Jumlah peserta tes yang menjawab benar pada kelompok atas

$\Sigma \mathrm{B} \quad=$ Jumlah peserta tes yang menjawab benar pada kelompok bawah

$\mathrm{n}_{\mathrm{A}}=$ Jumlah peserta tes pada kelompok atas
$\mathrm{n}_{\mathrm{B}}=\underset{\text { bawah }}{\text { Jumlah peserta tes pada kelompok }}$

Kriteria penelitian dari hasil analisis data didasarkan pada kriteria daya pembeda: DP $\geq$ $0,3=$ soal diterima; $0,10<\mathrm{DP}<0,29=$ soal direvisi; dan $\mathrm{DP}<0,10$ = soal ditolak (Sumarna, 2005).

\section{HASIL DAN PEMBAHASAN}

Produk yang dihasilkan dari penelitian pengembangan yang telah dilakukan adalah soal HOTS dengan wondershare quiz ceator sebagai media display pada pokok bahasan stoikiometri untuk kelas X SMA/MA sederajat yang sudah divalidasi. Model pengembangan yang digunakan pada penelitian adalah model Plomp. Uraian hasil penelitian pada setiap fase pengembangan Plomp yang telah dilakukan, dipaparkan sebagai berikut.

\subsection{Fase Investigasi Awal (Prelimenary Investigation)}

Fase investigasi awal terhadap soal HOTS dengan wondershare quiz creator sebagai media display yang dilakukan terdiri atas analisis ujung depan, peserta didik, materi dan kompetensi. Fase investigasi awal diperoleh hasil analisis sebagai berikut:

\subsubsection{Analisis Ujung Depan}

Permasalahan yang terjadi di lapangan adalah peserta didik responden mengalami kesulitan dalam pembelajaran kimia dan salah satu materi pembelajaran kimia yang dianggap sulit tersebut adalah materi stoikiometri, karena materi ini menuntut adanya pemahaman konsep dan analisis yang tajam untuk menyelesaikan soal-soalnya, menuntut peserta didik untuk terampil dalam perhitungan karena konsep-konsep dasar terkait dengan stoikiometri. Hasil analisis soal 
Pengembangan Soal HOTS dengan Wondershare Quiz Creator sebagai Media Display pada Materi Stoikiometri Kelas X

materi stokiometri yang digunakan masih berkisar $C_{1}$ sampai $C_{3}$ hanya mengukur kemampuan menghafal dan mengingat dari peserta didik belum mengukur kemampuan berpikir tingkat tinggi. Sehingga diperlukan suatu evaluasi soal HOTS dengan wondershare quiz creator sebagai media display pada pokok bahasan stoikiometri ini sehingga dapat menghantarkan peserta didik memenuhi kemampuan abad 21.

\subsubsection{Analisis Peserta Didik}

Tingkat perkembangan kognitif peserta didik SMA pada umumnya berusia 16-18 tahun. Menurut teori Piaget, peserta didik yang terletak pada tahap perkembangan operasi formal memiliki rentang usia 16-18 tahun, pada tahap ini peserta didik menarik kesimpulan, menafsirkan dan mengembangkan hipotesa (Piaget, 2002). Namun dengan membiasakan melatih soal HOTS dengan IT membuat peserta didik terbiasa mengerjakan soal berbasis IT.

\subsubsection{Analisis Kompetensi}

Analisis kompetensi terhadap stoikiometri diperoleh informasi bahwa stoikiomteri merupakan salah satu materi pembelajaran kimia yang terdapat pada kompetensi dasar 3.10 dan 4.10 .

\subsubsection{Analisis Materi}

Analisis materi ditujukan untuk menelaah konsep-konsep materi stoikiometri yang kemudian disusun secara sistematis. Menurut Watoni (2014) dalam materi stoikiometri, peserta didik mempelajari peserta didik mempelajari persamaan kimia, hukum-hukum dasar kimia serta konsep mol dan perhitungan.

\subsection{Fase Desain (Design)}

Hasil dari fase desain yang dilakukan antara lain: (a) Rancangan awal soal HOTS. dilakukan dengan tahapan yaitu menyusun kisi-kisi soal, menyusun soal, menyusun kunci jawaban dan pedoman penskoran, menyusun Lembar Validasi Materi. (b) Rancangan awal media display soal HOTS. Berupa soal HOTS dengan wondershare quiz creator pada pokok bahasan stoikiometri, rancangan instrumen lembar validasi oleh validator media beserta penjabaran instrumen lembar validasinya, desain kuesioner respon pengguna oleh guru dan peserta didik.

\subsection{Fase Realisasi (Realization)}

Fase realisasi pada penelitian ini dihasilkan prototipe yaitu soal HOTS dengan wondershare quiz creator sebagai media display dan instrumen lembar validasi dan kuesioner respon pengguna.

\subsection{Fase Validasi, Uji Coba dan Revisi (Evaluation, Test and Revision)}

Hasil dari validasi, uji coba dan revisi yaitu: (a) skor validasi soal HOTS; (b) skor validasi soal HOTS dengan wondershare quiz creator sebagai media dsiplay; (c) skor persentase kepraktisan soal HOTS dengan wondershare quiz creator sebagai media display.

Kegiatan validasi dilakukan oleh lima validator yang meliputi tiga orang dosen Program Studi Pendidikan Kimia, Universitas Riau dan dua dosen Jurusan Teknik Informatika, Universitas Islam Negeri Sultan Syarif Kasim Riau. Validasi materi berdasarkan aspek isi, konstruksi dan bahasa sedangkan pada validasi media berdasarkan aspek subtansi materi, desain pembelajaran, tampilan (komunikasi visual) dan pemanfaatan software menggunakan lembar validasi dan rubrik yang telah disediakan. Hasil rekap penilaian ketiga aspek (materi, konstruksi, dan bahasa) dari soal HOTS materi stoikiometri dari ketiga validator materi dapat dilihat pada Tabel 6. Nilai ketiga 
Pengembangan Soal HOTS dengan Wondershare Quiz Creator sebagai Media Display pada Materi Stoikiometri Kelas X

validator direratakan bertujuan untuk mengetahui kevalidan soal HOTS sesuai dengan rumus menurut Arikunto (2010) selain itu ketiga validator memiliki kompetensi yang setara dalam memvalidasi soal HOTS. Tabel 6 memuat keterangan nilai kevalidan soal HOTS yang terdiri dari dua paket yaitu paket $A$ dan paket $B$, setiap paket terdiri atas 5 soal dengan pengkategorian hasil persentase menurut Riduwan (2013).

Tabel 6. Hasil Perhitungan Validasi Aspek Materi, Konstruksi dan Bahasa

\begin{tabular}{|l|l|l|l|}
\hline \multirow{2}{*}{ No. Soal } & \multicolumn{3}{|c|}{ Aspek } \\
\cline { 2 - 4 } & Materi & Konstruksi & Bahasa \\
\hline Paket A & 4,33 & 4,33 & 4,78 \\
\hline 1 & 4,33 & 4,66 & 4,56 \\
\hline 2 & 5,00 & 4,89 & 4,67 \\
\hline 3 & 4,67 & 4,56 & 4,33 \\
\hline 4 & 4,67 & 4,78 & 4,89 \\
\hline 5 & & & \\
\hline Paket B & 5,00 & 5,00 & 5,00 \\
\hline 1 & 4,67 & 4,83 & 4,56 \\
\hline 2 & 5,00 & 4,83 & 4,11 \\
\hline 3 & 5,00 & 4,78 & 4,89 \\
\hline 4 & 5,00 & 4,94 & 4,78 \\
\hline 5 & 47,67 & 47,60 & 46,57 \\
\hline Skor Total & 4,767 & 4,760 & 4,657 \\
\hline Rata-rata & $95,34 \%$ & $95,20 \%$ & $93,14 \%$ \\
\hline Persentase & \multicolumn{2}{|l}{} \\
\hline Persentase Total & $\mathbf{9 4 , 5 6 \%}$ \\
\hline Kategori Sangat Valid & \\
\hline
\end{tabular}

Tabel 7. Hasil Validasi Oleh Validator Ahli Media

\begin{tabular}{|c|c|c|}
\hline $\begin{array}{c}\text { Aspek } \\
\text { Penilaian }\end{array}$ & $\begin{array}{c}\text { Persentase } \\
\text { Penilaian }\end{array}$ & Kategori \\
\hline Substansi Isi & 84 & Valid \\
\hline $\begin{array}{c}\text { Desain } \\
\text { Pembelajaran }\end{array}$ & 86 & $\begin{array}{c}\text { Sangat } \\
\text { Valid }\end{array}$ \\
\hline $\begin{array}{c}\text { Komunikasi } \\
\text { Visual }\end{array}$ & 84 & Valid \\
\hline $\begin{array}{c}\text { Pemanfaatan } \\
\text { Software }\end{array}$ & 88,57 & $\begin{array}{c}\text { Sangat } \\
\text { Valid }\end{array}$ \\
\hline \%Total & $\mathbf{8 5 , 6 4}$ & $\begin{array}{c}\text { Sangat } \\
\text { Valid }\end{array}$ \\
\hline
\end{tabular}

Berdasarkan Tabel 6. menunjukkan bahwa skor rata-rata keseluruhan validasi sebesar 94,56\% mencakup aspek materi, konstruksi dan bahasa, menurut Riduwan (2013), rentang nilai $81 \%-100 \%$ dalam kategori sangat valid. Grafik skor rata-rata validasi oleh ketiga validator untuk setiap aspek penilaian tertera pada Gambar 1.

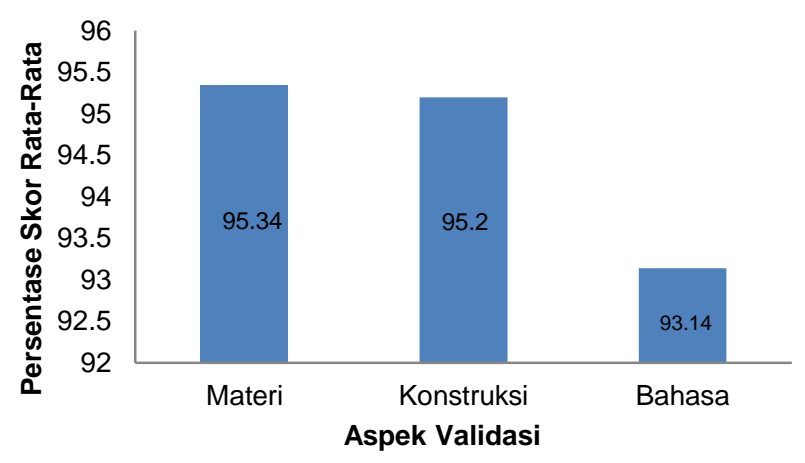

Gambar 1. Grafik Skor Validasi Tiga Validator.

Hasil rekap penilaian ketiga aspek oleh validator ahli media yaitu aspek subtansi materi, desain pembelajaran, tampilan (komunikasi visual) dan pemanfaatan software) dari soal HOTS dengan wondershare quiz creator sebagai media display pada materi stoikiometri dari kedua validator media dapat dilihat pada Tabel 7 dengan pengkategorian hasil persentase menurut Widoyoko (2012). Adapun diagram persentase skor peningkatan validitas berbagai aspek oleh validator ahli media disajikan pada Gambar 2.

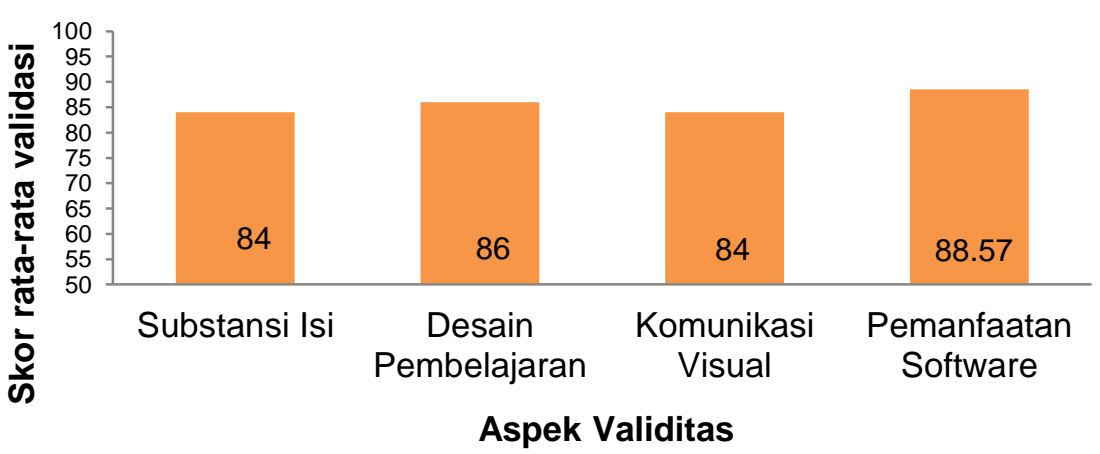

Gambar 2. Skor Rata-Rata Validasi Berbagai Aspek oleh Validator Ahli Media

Jurnal Tadris Kimiya 4, 2 (Desember 2019): 177-188

This is an open access article under CC-BY-SA license (https://creativecommons.org/licenses/by-sa/4.0/) 
Pengembangan Soal HOTS dengan Wondershare Quiz Creator sebagai Media Display pada materi Stoikiometri Kelas $X$

Hasil validasi produk soal mendapatkan saransaran yang membangun dari validator materi, diantaranya perbaikan penulisan soal, perbaikan redaksi soal, rumusan soal yang rancu, dan perbaiki konsep materi dalam soal. Perbaikan kesalahan dalam penulisan/pengetikan dalam butir soal bertujuan untuk menghindari typo sehingga peserta didik tidak terjadi multitafsir terhadap soal. Semua soal yang dikembangkan sesuai dengan komponen penilaian, namun diantara ketiga aspek penilaian aspek bahasa memiliki persentase paling rendah, hal ini dikarenakan masih banyaknya penggunaan kalimat yang kurang tepat dan bahasa yang sulit dipahami dalam soal HOTS untuk mengidentifikasi penyelesaian masalah dalam soal. Tetapi penilaian keseluruhan dari tiga validator memiliki persentase yang tinggi yaitu 94,56\% artinya semua soal yang dikembangkan memiliki kriteria sangat valid. Menurut Riduwan (2013) rentang nilai 81\%-100\% dalam kategori sangat valid. Hasil validasi soal HOTS dengan wondershare quiz creator sebagai media display dengan saran dan komentar yang secara keseluruhan mengindikasikan bahwa soal HOTS dengan wondershare quiz creator sebaiknya dapat dilihat secara fullscreen, memiliki petunjuk penggunaan yang dinilai tidak dapat memberikan informasi keseluruhan terkait bagaimana penggunaan yang semestinya, tidak menampilkan informasi identitas penyusun yang lebih detail pada halaman depan, dan beberapa kalimat dinilai tidak memenuhi ejaan yang disempurnakan, Sehingga, perlu dilakukan revisi sesuai saran dan komentar yang diberikan. Hasil validasi oleh validator media menunjukkan bahwa persentase rata-rata skor validasi yang dianalisis dari validator media $85,64 \%$. Menurut Widoyoko (2012) persentase skor tersebut berada pada range persentase skor 85,33\%-100\% dengan kriteria sangat valid.
Uji coba (test) pertama dilakukan dengan menunjukkan soal HOTS dengan wondershare quiz creator sebagai media display pada pokok bahasan stoikiometri menggunakan kuesioner respon pengguna oleh guru dan peserta didik. Uji coba kepada guru responden dilakukan kepada tiga orang guru kimia SMA yang meliputi seorang guru kimia dari SMA Cendana Pekanbaru, SMA Negeri 8 Pekanbaru dan MAN 2 Model Pekanbaru. Uji coba kepada guru responden dilakukan secara langsung dihadapan peneliti menggunakan laptop. Uji coba ini diawali dengan pengoperasian soal HOTS dengan wondershare quiz creator pada pokok bahasan stoikiometri oleh guru responden yang bersangkutan. Kemudian diberikan kuesioner respon pengguna oleh guru dan melakukan penilaian soal HOTS dengan wondershare quiz creator pada pokok bahasan stoikiometri. Persentase skor total respon guru 90,67\% menurut Widoyoko (2012) persentase skor tersebut berada pada range 85,33-100 diperoleh kriteria sangat baik sehingga dapat diperoleh soal HOTS dengan wondershare quiz creator sebagai media display pada pokok bahasan stoikiometri layak digunakan oleh guru dalam evaluasi pembelajaran.

Uji coba kepada peserta didik responden dilakukan secara langsung oleh peneliti dan didampingi guru kimia bersangkutan yang sebagian besar menggunakan laptop. Uji coba ini diawali dengan pengumpulan peserta didik sebagai responden oleh guru kimia bersangkutan dan peneliti memberikan penjelasan singkat terkait penggunaan soal HOTS dengan wondershare quiz creator sebagai media display pada pokok bahasan stoikiometri dan kilas balik agar peserta didik responden dapat terlatih dalam mengerjakan soal HOTS berbasis IT. Kemudian, masingmasing peserta didik diberikan kuesioner respon pengguna oleh perserta didik untuk 
Pengembangan Soal HOTS dengan Wondershare Quiz Creator sebagai Media Display pada materi Stoikiometri Kelas $X$

melakukan penilaian. Persentase rata-rata seluruh pernyataan dalam kuesioner respon pengguna oleh peserta didik adalah 91,20\% menurut Yamasari (2010) persentase skor tersebut berada pada range persentase skor 80,00\%-100\% dengan kriteria sangat baik, sehingga dapat diperoleh pengendalian soal HOTS dengan wondershare quiz creator sebagai media display pada pokok bahasan stoikiometri layak digunakan oleh peserta didik dalam evaluasi pembelajaran. Kemudian hasil yang diperoleh dari jawaban peserta didik dalam mengerjakan soal HOTS dengan wondershare quiz creator dianalisis dan ditentukan reliabilitas, taraf kesukaran dan daya pembeda.

Uji reliabilitas dilakukan dengan menggunakan rumus Spearman Brown. Nilai uji reliabilitas yang diperoleh pada paket $A$ dan paket $B$ adalah sebesar 0,73 dan 0,71 berdasarkan kriteria reliabilitas pada Tabel 4 menurut Arikunto (2010) nilai uji reliabilitas berada pada rentang nilai $0,61-0,80$ dengan kriteria tinggi, sehingga dapat diperoleh soal HOTS dengan wondershare quiz creator sebagai media display pada pokok bahasan stoikiometri reliabel. Taraf kesukaran butir soal digunakan untuk mengetahui tingkat kesukaran butir soal. Taraf kesukaran soal diperoleh hasil seperti pada Tabel 8.

Tabel 8. Taraf Kesukaran Soal

\begin{tabular}{|c|c|c|}
\hline Nomor Soal & Tingkat Kesukaran & Kriteria \\
\hline A. Paket A & 0,44 & Sedang \\
\hline 1 & 0,36 & Sedang \\
\hline 2 & 0,28 & Sukar \\
\hline 3 & 0,24 & Sukar \\
\hline 4 & 0,28 & Sukar \\
\hline 5 & 0,45 & Sedang \\
\hline B. Paket B & 0,25 & Sukar \\
\hline 1 & 0,25 & Sukar \\
\hline 2 &
\end{tabular}

\begin{tabular}{|c|c|c|}
\hline Nomor Soal & Tingkat Kesukaran & Kriteria \\
\hline 4 & 0,25 & Sukar \\
\hline 5 & 0,50 & Sedang \\
\hline
\end{tabular}

Tabel 8 menunjukkan pengolahan data taraf kesukaran butir soal dan diperoleh tingkat kesukaran sedang sebanyak 4 butir soal dan tingkat kesukaran sukar sebanyak 6 soal menurut Arikunto (2010) tingkat kesukaran sedang berada pada range 0,31- 0,70 dan tingkat kesukaran sukar berada pada range $0,00-0,30$ sehingga dapat diperoleh soal HOTS dengan wondershare quiz creator sebagai media display pada pokok bahasan stoikiometri layak digunakan. Daya Pembeda (DP) soal diperoleh hasil seperti pada Tabel 9.

Tabel 9. Hasil Perhitungan DP Butir Soal

\begin{tabular}{|c|c|c|}
\hline Nomor Soal & $\begin{array}{c}\text { Tingkat } \\
\text { Kesukaran }\end{array}$ & Kriteria \\
\hline A. Paket A & 0,71 & Soal diterima \\
\hline 1 & 0,71 & Soal diterima \\
\hline 2 & 0,57 & Soal diterima \\
\hline 3 & 0,71 & Soal diterima \\
\hline 4 & 0,57 & Soal diterima \\
\hline 5 & & \\
\hline B. Paket B & 0,80 & Soal diterima \\
\hline 1 & 0,80 & Soal diterima \\
\hline 2 & 0,60 & Soal diterima \\
\hline 3 & 0,40 & Soal diterima \\
\hline 4 & 0,10 & Soal diterima \\
\hline 5 &
\end{tabular}

Tabel 9 menunjukkan pengolahan data daya pembeda butir soal dan diperoleh soal diterima dalam 10 butir soal menurut Sumarna (2005) daya pembeda $\geq 0,3$ termasuk kategori soal diterima sehingga dapat diperoleh soal HOTS dengan wondershare quiz creator sebagai media display pada pokok bahasan stoikiometri dapat digunakan dalam evaluasi pembelajaran kimia. 
Pengembangan Soal HOTS dengan Wondershare Quiz Creator sebagai Media Display pada materi Stoikiometri Kelas $X$

\section{KESIMPULAN}

Berdasarkan hasil penelitian dan pembahasan yang telah dilakukan diperoleh soal HOTS dengan wondershare quiz creator sebagai media display pada pokok bahasan stoikiometri untuk kelas X SMA/MA sederajat yang valid dan reliabel yang telah melalui proses validasi oleh validator materi berdasarkan aspek materi dengan persentase 95,34\%, aspek konstruksi 95,20\% dan aspek bahasa $93,14 \%$. Kemudian oleh validator ahli media berdasarkan aspek subtansi materi dengan persentase $84,00 \%$, desain pembelajaran $86,00 \%$, komunikasi visual $84,00 \%$ dan pemanfaatan software $88,57 \%$. Selain itu, soal HOTS dengan wondershare quiz creator sebagai media display pada pokok bahasan stoikiometri untuk kelas X SMA/MA sederajat layak digunakan dan telah melalui proses uji coba respon pengguna oleh guru dan peserta didik dengan persentase $90,67 \%$ dan $91,20 \%$ dengan kriteria sangat baik. 
Pengembangan Soal HOTS dengan Wondershare Quiz Creator sebagai Media Display pada materi Stoikiometri Kelas $X$

\section{DAFTAR PUSTAKA}

Afriani, A., Setyarini, M., \& Efkar, T. (2018). Pengembangan Instrumen Asesmen Pengetahuan Berbasis HOTS pada Materi Elektrolit dan Nonelektrolit. Jurnal Pendidikan Kimia, 1(1), 1 - 12.

Arikunto, S. (2010). Manajemen Penelitian. Jakarta: Rineka Cipta.

Brookhart, S. M. (2010). How to assess higherorder thinking skills in your classroom. ASCD.

Depdiknas. (2008). Panduan Pengembangan Bahan Ajar. Jakarta: Direktorat Pembinaan Sekolah Menengah Atas Direktorat Jenderal Manajemen Pendidikan Dasar dan Menengah Departemen Pendidikan Nasional.

Hernawati, K. (2009). Pelatihan Penyusunan Soal Matematika Interaktif Berbasis Web dengan Menggunakan Perangkat Lunak Bantu Wondershare Quiz Creator. Yogyakarta: Laboratorium Komputer Jurusan Pendidikan Matematika FMIPA UNY.

Iqbal, W.M.G., Fadhilah, R., Hadiarti, D. (2018). Pengembangan Alat Evaluasi Berbasis Wondershare Quiz Creator pada Materi Koloid Kelas XI di SMA Koperasi Pontianak. Ar-Razi Jurnal Ilmiah, 6(1), 11-19.

Kemendikbud. (2017). Panduan Implementasi Kecakapan Abad 21 Kurikulum 2013 di Sekolah Menengah Atas. Jakarta: Badan Pengembangan Sumber Daya Manusia Pendidikan dan Kebudayaan dan Penjaminan Mutu Pendidikan.

Krathwohl, D. R., \& Anderson, L. W. (2009). A taxonomy for learning, teaching, and assessing: A revision of Bloom's taxonomy of educational objectives. Longman.
Piaget, J. (2002). Tingkat Perkembangan Kognitif. Jakarta: Gramedia.

Riduwan. (2013). Dasar - Dasar Statistika. Bandung: Alfabeta.

Rochmad, R. (2012). Desain Model Pengembangan Perangkat Matematika. Jurnal Kreano. 3 (1), 59-72.

Rohmad, A., Suhandini, P., Sriyanto. (2013). Pengembangan lembar kerja peserta didik (LKS) berbasis eksplorasi, elaborasi dan konfirmasi (EEK) serta kebencanaan sebagai bahan ajar mata pelajaran geografi SMA/MA di Kabupaten Rembang. Jurnal Edu Geography, 1(2), 1 5.

Senjaya, W. (2008). Strategi Pembelajaran Berorientasi Standar Proses Pendidikan. Jakarta: Kencana Prenada media Group.

Sugiyono. (2005). Metode Penelitian Kuantitatif Kualitatif dan R\&D. Bandung: Alfabeta.

Sumarna, S. (2005). Analisis, Validitas, Reliabilitas dan Interpretasi Hasil Tes: Implementasi Kurikulum 2004. Bandung: Remaja Rosdakarya.

Watoni, A.H. (2014). Kimia Untuk SMA/MA Kelas XI (Peminatan). Bandung: Yrama Widya.

Widoyoko, E.P. (2012). Panduan Pengembangan Bahan Ajar Berbasis TIK. Yogyakarta: Pustaka Belajar.

Yamasari, Y. (2010). Pengembangan Media Pembelajaran Matematika Berbasis ICT yang Berkualitas. Makalah disajikan dalam Seminar Nasional Pascasarjana. Surabya: FMIPA UNESA. 